\title{
Pengaruh Brace terhadap Kekuatan Kaki Struktur Helideck dalam Menahan Beban Pendaratan Darurat Helikopter
}

\author{
Anwar $^{1 *}$, Ganding Sitepu ${ }^{1}$, Muhammad Zubair Muis Alie ${ }^{1}$ \\ ${ }^{1}$ Departemen Teknik Perkapalan, Fakultas Teknik, Universitas Hasanuddin \\ J1. Poros Malino km.6, Bontomarannu, Kabupaten Gowa, Sulawesi Selatan 92171 \\ *Email: anwar.st.07@gmail.com
}

DOI: 10.25042/jpe.112018.11

\begin{abstract}
Abstrak
Brace dan kaki struktur menjadi perhatian penting dalam merencanakan struktur helideck. Penelitian ini bertujuan menghitung kekuatan kaki struktur helideck terhdap variasi brace dalam menahan beban pedaratan darurat helikopter. Lokasi penelitian dilakukan di laboratorium Struktur Departemen Perkapalan, Fakultas Teknik, Universitas Hasanuddin. Data yang digunakan adalah struktur helideck FSO Geudondong PT. Pertamina Shipping Indonesia corporation. Perhitungan tegangan dan pemodelan struktur menggunakan software SACS, analisis pendaratan darurat helikopter dibagi menjadi tiga arah pendaratan yaitu arah transversal, logitudinal dan arah diagonal. Dalam mencari dimensi kaki yang optimal maka dilakukan pengurangan tebal dan diameter kaki struktur helideck sebesar 10\%, 20\%, 30\% dan 40\% dengan empat variasi model brace yaitu brace $\mathrm{X}, \mathrm{K}, \mathrm{N}$ dan $\mathrm{Y}$. Hasil perhitungan tegangan maksimum yang bekerja terjadi pada posisi pendartan diagonal pada posisi D4 dengan tegangan kerja sebesar 49,86 N/mm² dan nilai IR 0,45 . Interaksi rasio (IR) yang terjadi pada kaki struktur pada pengurangan dimensi $40 \%$ sebesar (brace $\mathrm{X}=0,99)$, (brace $\mathrm{K}=1,19)$, (brace $\mathrm{N}=1,04$ ), (brace $\mathrm{Y}=$ 1,03). Model brace yang paling lemah dalam menahan beban pendaratan darurat helikopter adalah model brace $\mathrm{K}$ dengan $(I R=1,19)$ dan model brace yang paling kuat adalah adalah brace $\mathrm{X}$ dengan $I R=0,99$.
\end{abstract}

\begin{abstract}
The effect of Brace on the Leg Strength of Helideck Structure to hold the Load of Helicopter's Emergency Landing. Brace and leg structure are important concern in planning a helideck structure. The objective of this study is to calculate the leg strength of helideck structure on brace variations to hold the load of helicopter's emergency landing. The research was conducted in Structure Laboratory of Naval Engineering Department, Faculty of Engineering, Hasanuddin University, using helideck structure data of FSO Geudondong, Pertamina Shipping Indonesia Corporation. Strength analyzing and structure modeling used SACS software. The analysis of helicopter's emergency landings is divided into three landing directions. They are transversal direction, longitudinal and diagonal directions. In searching the optimal leg dimension, we reduce the thickness and diameter of leg's helideck structure by $10 \%, 20 \%, 30 \%$ and $40 \%$ with four variations of the brace model. They are brace $\mathrm{X}, \mathrm{K}, \mathrm{N}$ and $\mathrm{Y}$. The maximum stress calculation result which work in landing diagonal position on D4 position with working stress of $49.86 \mathrm{~N} / \mathrm{mm} 2$ and IR value of 0.45 . Interaction ratio (IR) that occurs on the legs of the structure in dimension reduction of $40 \%$ by (brace $X=0.99$ ), (brace $K=1.19$ ), (brace $N=1.04$ ), (brace $Y=1.03$ ). The weakest brace model in holding helicopter's emergency landing loads is the K brace model with (IR $=1.19)$ and the strongest brace model is brace $\mathrm{X}$ with IR $=0.99$.
\end{abstract}

Kata Kunci: Kekuatan struktur, pendaratan darurat, variasi brace

\section{Pendahuluan}

Kegiatan eksplorasi minyak dan gas dilakukan dalam periode waktu yang lama dan biasanya kegiatan ini dilakukan di laut yang dalam serta jauh dari daratan. Untuk memudahkan transportasi crew/client serta untuk evakuasi dalam kondisi darurat dan medis diperlukan transportasi yang cepat, nyaman, dan mudah yaitu helikopter. Sehingga anjungan lepas pantai harus dilengkapi dengan helideck untuk proses pendaratan helikopter. Struktur ini harus dirancang sedemikian rupa agar memiliki interaksi yang tepat dengan platform. Selain itu helideck dan struktur pendukungnya merupakan elemen penting keselamatan karena perannya dalam proses evakuasi darurat, dan juga selama operasi normal [1].

Platform fixed jacket adalah jenis struktur kolom yang menahan beban aksial dan beban 
lateral. Beban aksial umumnya didistribusikan ke semua kaki jaket dalam arah vertikal dan sebaliknya, beban lateral bekerja pada komponen struktural, seperti diagonal dan horizontal brace, termasuk elemen jaket [2]. Helideck merupakan tempat pendaratan dan lepas landas helikopter pada anjungan bangunan lepas pantai [3]. Ajungan bangunan lepas pantai memiliki fasilitas helideck khususnya anjungan yang cukup jauh dari pantai. Ukuran serta dimensi helideck pada anjungan lepas pantai sangatlah bervariasi, karena disesuaikan dengan panjang helikopter keseluruhan [4]. Peningkatan struktur helideck semakin besar dikarenakan Jumlah struktur anjungan lepas pantai yang meningkat seiring meningkatnya permintaan minyak dan gas [5].

Kekuatan struktur helideck menjadi perhatian penting karena kekuatan struktur merupakan kemampuan struktur dalam menahan gaya atau beban yang bekerja [6]. Kekuatan dianalisis berdasarkan beban-beban yang bekerja pada struktur helideck, atau berat helikopter, bahan atau material utama struktur helideck adalah baja. Untuk mengetahui apakah rancangan struktur helideck tersebut aman sesuai dengan kriteria maka perlu kajian kekuatan struktur dengan melakukan perhitungan beban serta simulasi pembebanan dengan menggunakan Metode Elemen Hingga [7].

Dalam merencenakan struktur helideck penentuan model brace struktur sangatlah penting untuk dilakukan, dimana menurut [8] brace memiliki fungsi untuk meningkatkan kekakuan pada kaki struktur helideck sehingga struktur tersebut memiliki tingkat kekuatan yang tiggi. Model brace memiliki banyak tipe model antara lain brace X, K, N, Y, T. Model tersebut masingmasing memiliki bentuk dan karakteristik yang berbeda sehingga model tersebut dapat dipilih sesuai dengan kebutuhan struktur. Tipe brace juga mempertimbangkan masalah ekonomi dalam hal ini efektivitas biaya konstruksi helideck.

Beban helikopter yang digunakan dalam merancang struktur helideck pada anjungan lepas pantai yaitu menggunakan berat maksimum dari helikopter [9]. Dimensi helikopter memiliki ukuran panjang, berat serta diameter baling-baling yang bervariasi sehingga pemilihan tipe helikopter disesuaikan dengan kebutuhan operasional pada anjungan lepas pantai yang akan dibangun dan dioperasikan.

\section{Metode Penelitian}

\subsection{Data Penelitian}

Data struktur yang digunakan adalah model struktur helideck FSO Geudondong PT. Pertamina Indonesia dengan data sebagai berikut:

Ukuran utama helideck:

1. Struktur : Helideck

2. Tinggi : 17,85 meter

3. Luas pendaratan: $19,5 \times 19,5 \mathrm{~m}$

Data Helikopter [10]

1. Nama helikopter : Eurocopter

2. Tipe : EC 225

3. Panjang keseluruhan $: 19,50$ Meter

4. Berat maksimum : 10,4 ton

5. Diameter Rotor : : 16,18 Meter

Data Komponen struktur helideck dapat dilihat pada Tabel 1.

Tabel 1. Dimensi material struktur helideck

\begin{tabular}{|c|c|c|c|}
\hline Bagian & \multicolumn{2}{|c|}{$\operatorname{Ukuran}(\mathbf{m m})$} & Jenis profil \\
\hline Kaki struktur & $\varnothing=355$ & $\mathrm{t}=19$ & Tubular \\
\hline Brace 1 & $\varnothing=168$ & $\mathrm{t}=11$ & Tubular \\
\hline Brace 2 & $\varnothing=219$ & $t=15$ & Tubular \\
\hline $\begin{array}{l}\text { Gelagar } \\
\text { geladak }\end{array}$ & WF 400 & $15 \times 10$ & Wide Flange \\
\hline Girder & L $160 \times 1$ & & L \\
\hline Pelat & 12 & & \\
\hline
\end{tabular}

Beban helikopter yang digunakan adalah berat maksimum dari helikopter, dalam perhitungan beban pendaratan darurat helikopter menurut [4] adalah 2,5 x berat maksimum helikopter ditambah dengan faktor dinamis $1,3 \mathrm{x}$ berat maksimum helikopter. Tegangan yang bekerja pada struktur helideck harus lebih kecil dari tegangan yang di ijinkan atau $I R \leq 1$. Interaksi rasio sendiri merupakan hasil kombinasi dari tegangan kerja aksial dan tegangan kerja bending dibagi dengan tegangan yang dijinkan [6]. dengan persamaan sebagai berikut:

$$
I R=\frac{\sigma_{a}}{\sigma_{a i}}+\frac{\sigma_{b}}{\sigma_{b i}}
$$


dimana:

$$
\begin{array}{ll}
\sigma_{\mathrm{a}} & : \text { Tegangan kerja aksial } \\
\sigma_{\mathrm{b}} & : \text { Tegangan kerja bending } \\
\sigma_{\mathrm{ai}} & : \text { Tegangan ijin aksial } \\
\sigma_{\mathrm{bi}} & : \text { Tegangan ijin bending }
\end{array}
$$

\subsection{Analisis dengan software SACS}

SACS adalah software yang digunakan untuk Perhitungan dinamik dan statik baik untuk struktur offshore maupun untuk aplikasi teknik sipil umum. SACS memiliki beberapa analisis program struktur yang sesuai dengan kebutuhan penggunanya. Untuk menjalankan SACS, dibutuhkan data geometri, dimensi member, property material dan kondisi lingkungan yang dijadikan sebagai input pada program tersebut. Program SACS menghasilkan solusi umum yang mengandung displacement joint dan gaya internal. Proses pada program akan menggunakan data tersebut dalam menganalisis kekakuan struktur dengan menggunakan beberapa codes structural. Dengan software SACS, dilakukan pemodelan struktur helideck serta analisis kekuatan dan tegangan yang bekerja sehingga akan mengeluarkan hasil yang sesuai dengan pemodelan dan analisis yang dilakukan.

\section{Hasil dan Pembahasan}

\subsection{Pemodelan struktur helideck dengan SACS}

Pada proses pemodelan struktur helideck langkah pertama yang dilakukan adalah membuka tap modeling pada software SACS, proses pemodelan ini adalah kegiatan menyambung elemen-elemen struktur seperti member yang disambungkan antar joint baik itu secara vertikal ataupun secara horizontal sehingga membentuk suatu model bangunan yang utuh yaitu model struktur helideck. Setelah model struktur terbentuk maka langkah selanjutnya adalah mengatur spesifikasi material yang digunakan seperti modulus elastis, tegangan luluh bahan, tebal material, diameter kaki struktur dan unsurunsur lain pada struktur. Pemodelan struktur helideck sendiri disesuaikan dengan data yang dimiliki baik itu untuk ukuran luasan helideck ataupun ukuran dimensi pada struktur helideck itu sendiri.
Berikut adalah model struktur helideck yang telah dibuat pada software SACS seperti pada Gambar 1.

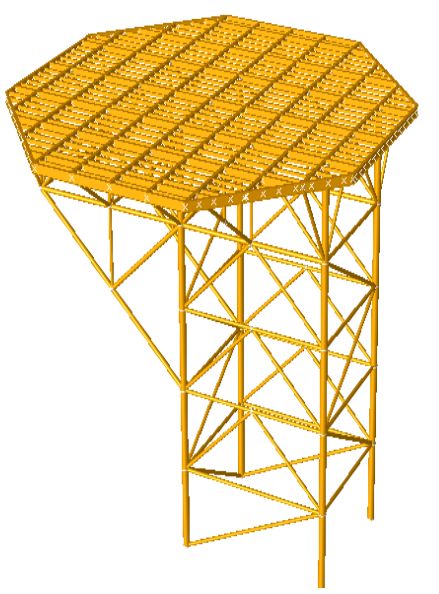

Gambar 1. Model helideck 3 dimensi

\subsection{Posisi Pendaratan}

Pada posisi pendaratan helikopter terdapat tiga arah pendaratan dengan masing-masing memiliki empat posisi jarak pendaratan yang berbeda beda, posisi pendaratan ini diberi nama pendaratan arah transversal, arah logitudinal dan pendaratan arah diagonal, pendaratan posisi transversal memiliki 4 posisi yaitu posisi T1, T2, T3, dan Posisi T4 sedangkan arah logitudinal yaitu posisi L1, L2, L3, Posisi L4 dan arah diagonal yaitu posisi D1, D2, D3 dan posisi D4.

- Pendaratan darurat arah transversal

Pendaratan arah transversal merupakan pendaratan darurat dengan lokasi pendaratan menyimpang ke kiri dari arah pendaratan normal helikopter. Posisi T1 merupakan posisi pendaratan yang bergeser ke luar lingkaran pendaratan helikopter dengan jarak roda belakang sebelah kiri helikopter berada 1 meter dari lingkaran pendaratan normal helikopter, selanjutnya posisi pendaratan T2 posisi roda sebelah kiri menyimpang 2 meter, posisi pendaratan T3 menyimpang 3 meter dan posisi pendartan T4 menyimpang 4 meter ke arah kiri luar lingkaran pendaratan normal helikopter. Untuk memperjelas posisi pendaratan darurat helikopter dapat dilihat pada Gambar 2. 


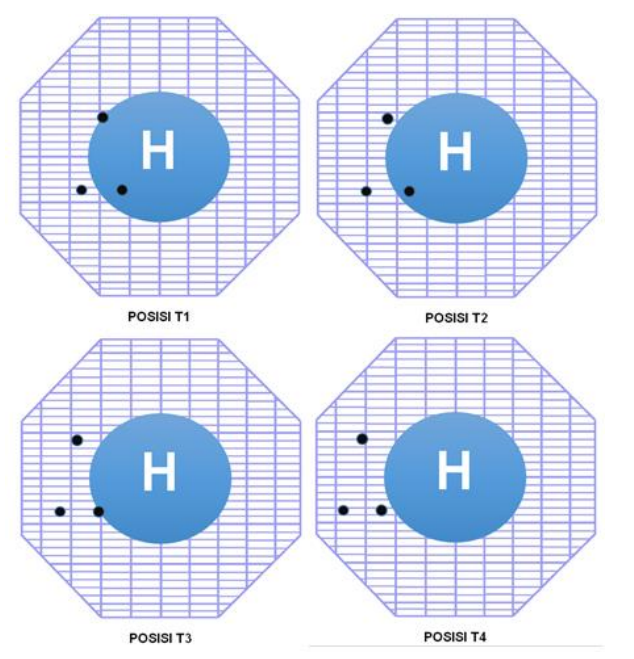

Gambar 2. Pendaratan darurat arah transversal

- Pendaratan darurat arah logitudinal

Pendaratan arah logitudinal yaitu posisi pendaratan darurat yang menyimpang ke arah belakang pendaratan helikopter dimana pada pendaratan arah logitudinal, dua roda belakang helikopter berada diluar lingkaran pendaratan normal. Pada arah logitudinal terdapat empat simpangan yaitu posisi L1 menyimpang 1 meter, L2 menyimpang 2 meter, L3 menyimpang 3 meter dan Posisi L4 menyimpang 4 meter. Untuk lebih jelasnya dapat dilihat pada Gambar 3.

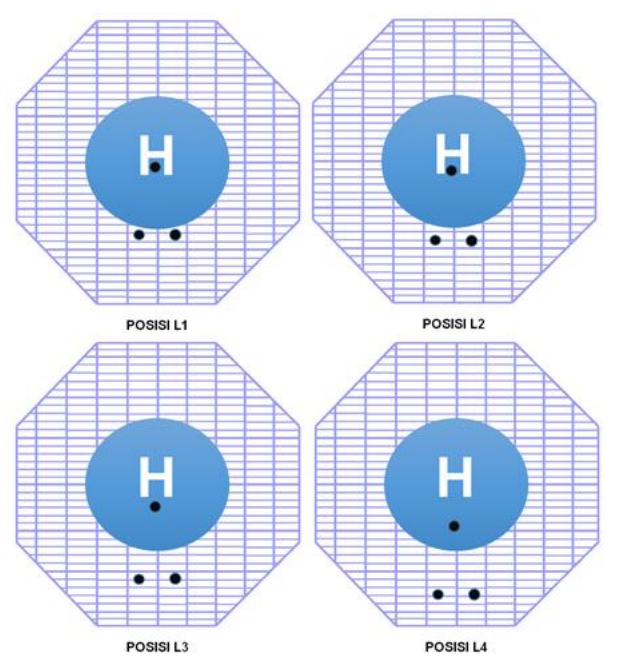

Gambar 3. Pendaratan darurat arah longitudinal

- Pendaratan darurat arah diagonal

Pendaratan arah diagonal merupakan pendaratan darurat dengan lokasi pendaratan menyimpang ke kiri dari arah pendaratan normal helikopter secara diagonal. Posisi D1 merupakan posisi pendaratan yang bergeser ke luar lingkaran pendaratan helikopter dengan jarak roda belakang sebelah kiri helikopter berada 1 meter dari lingkaran pendaratan helikopter, selanjutnya posisi pendaratan D2 posisi roda sebelah kiri menyimpang 2 meter, posisi D3 menyimpang 3 meter dan posisi D4 menyimpang 4 meter ke arah kiri luar lingkaran pendaratan helikopter dengan arah diagonal. Untuk lebih jelasnya dapat dilihat pada Gambar 4.

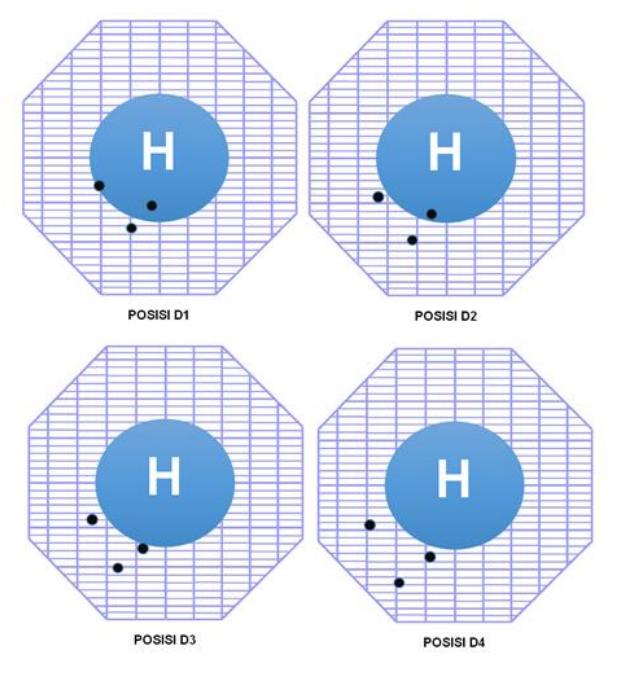

\section{Gambar 4. Pendaratan darurat arah diagonal}

Posisi pendaratan diatas merupakan posisi kemungkinan pendaratan darurat helikopter. Pendaratan normal adalah pendaratan yang dilakukan didalam lingkaran [2]. lingkaran berwarna biru merupakan area pendaratan dimana helikopter pada saat mendarat secara normal berada diarea lingkaran tersebut.

\subsection{Hasil Analisis Pendaratan Darurat}

Analisis pendaratan darurat merupakan analisis untuk mengetahui dampak pembebanan helikopter pada saat melakukan pendaratan darurat untuk posisi yang beragam yang kemungkinan dapat terjadi pada struktur helideck. Seperti yang dijelaskan diatas posisi pendaratan darurat helikopter berjumlah 12 posisi pendartan dengan 3 arah pendaratan. Pada analisis ini proses running pada software SACS dilakukan untuk tiap-tiap posisi pendaratan sehingga masingmasing posisi memiliki data hasil running seperti pada Tabel 2 . 
Tabel 2. Pendaratan darurat helicopter

\begin{tabular}{cccc}
\hline Jarak & \multicolumn{3}{c}{ Interaksi Rasio $($ IR) } \\
Pendaratan & T & L & D \\
\hline 1 & 0,33 & 0,33 & 0,35 \\
2 & 0,35 & 0,35 & 0,37 \\
3 & 0,36 & 0,37 & 0,40 \\
4 & 0,38 & 0,39 & 0,45 \\
\hline
\end{tabular}

Hasil dari Tabel 2 menunjukkan bahwa pendaratan darurat dengan nilai $I R$ terbesar adalah pendaratan darurat dengan posisi pendaratan arah diagonal dengan jarak empat meter dengan Posisi D4. Posisi pendaratan tersebut merupakan posisi yang paling besar memberikan gaya kepada kaki struktur helideck sehingga posisi pendaratan darurat D4 dipilih dan digunakan pada pembebanan pendaratan darurat untuk model brace dan pembebanan pada proses pengurangan dimensi kaki struktur helideck. Hasil pendaratan darurat dapat dilihat pada Gambar 5.

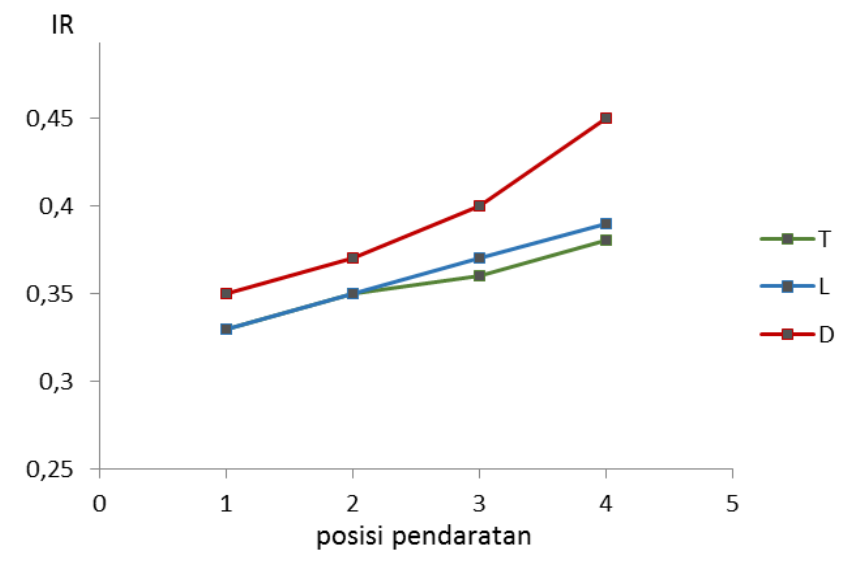

Gambar 5. grafik $I R$ pendaratan darurat helicopter

\subsection{Hasil Pengurangan Dimensi Kaki Struktur}

Proses ini dilakukan dengan pengurangan dimensi antara diameter dan ketebalan kaki struktur helideck secara bertahap mulai dari 10\%, 20\%, 30\%, hingga 40\%. Masing-masing struktur dihitung berdasarkan variasi brace. simulasi ini dilakukan untuk mengetahui berapa diameter dan ketebelan kaki struktur yang optimum dengan berbagai variasi brace. Berikut hasil perhitungan tegangan dan $I R$ untuk tiap-tiap model brace.
- Model brace X

Dari hasil running analisis pada helideck dengan model brace $\mathrm{X}$ maka diperoleh tegangan maksimum dan nilai $I R$ untuk masing - masing pengurangan dimensi pada kaki struktur seperti pada Tabel 3 .

Tabel 3. Tegangan dan IR model brace $\mathrm{X}$

\begin{tabular}{ccc}
\hline $\begin{array}{c}\text { Pengurangan } \\
\text { dimensi }\end{array}$ & $\begin{array}{c}\boldsymbol{\sigma} \\
\left(\mathbf{N} / \mathbf{m m}^{\mathbf{2}}\right)\end{array}$ & $\boldsymbol{I R}$ \\
\hline $0 \%$ & 45,88 & 0,40 \\
$10 \%$ & 56,16 & 0,48 \\
$20 \%$ & 70,46 & 0,60 \\
$30 \%$ & 91,25 & 0,78 \\
$40 \%$ & 114,12 & 0,99 \\
\hline
\end{tabular}

Hasil running menunjukkan tegangan kerja model brace $\mathrm{X}$ untuk pengurangan dimensi kaki struktur $0 \%$ sebsar $45,88 \mathrm{~N} / \mathrm{mm}^{2}$ sedangkan untuk tengangan maksimum pada pengurangan $40 \%$ adalah sebesar $114,12 \mathrm{~N} / \mathrm{mm}^{2}$. Adapun nilai pengurangan dimensi terhadap tegangan kerjamaksimum dapat dilihat pada Gambar 6.

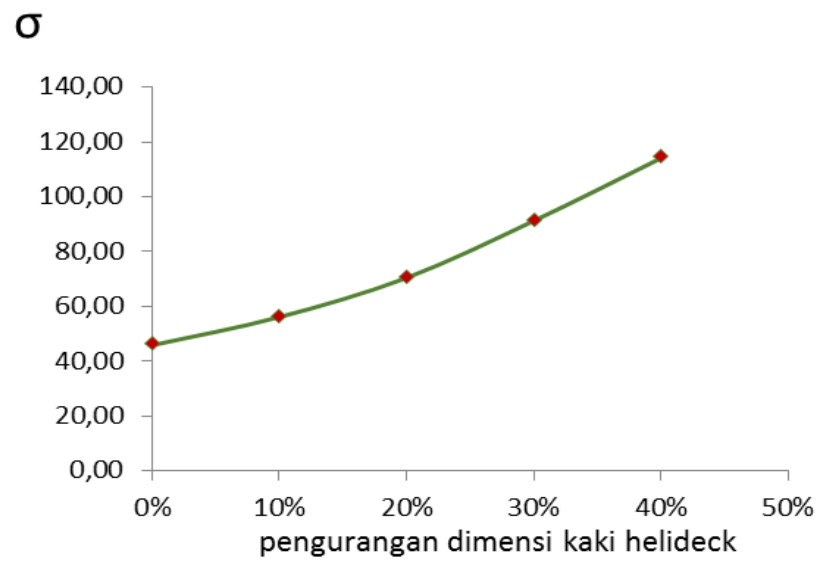

Gambar 6. Tegangan terhadap pengurangan dimensi

- Model brace $\mathrm{N}$

Dari hasil running analisis pada software SACS maka diperoleh hasil tegangan kerja maksimum dan nilai $I R$ pada model brace $\mathrm{N}$ seperti pada Tabel 4.

Dari hasil running analisis, model brace $\mathrm{N}$ memiliki tegangan kerja pada pengurangan dimensi $0 \%$ sebasar 46,24 N/mm ${ }^{2}$ sedankan untuk pengurangan dimensi sebsar $40 \%$ tengan kerja maksimum sebsara $116,87 \mathrm{~N} / \mathrm{mm}^{2}$. Adapun data 
perbandingan antara tegangan kerja dan pengurangan dimensi dapat dilihat pada Gambar 7.

Tabel 4. Tegangan dan $I R$ model brace $\mathrm{N}$

\begin{tabular}{ccc}
\hline $\begin{array}{c}\text { Pengurangan } \\
\text { dimensi }\end{array}$ & $\boldsymbol{\sigma}\left(\mathbf{N} / \mathbf{m m}^{\mathbf{2}}\right)$ & $\boldsymbol{I R}$ \\
\hline $0 \%$ & 46,24 & 0,42 \\
$10 \%$ & 56,72 & 0,50 \\
$20 \%$ & 71,40 & 0,62 \\
$30 \%$ & 92,94 & 0,81 \\
$40 \%$ & 116,87 & 1,04 \\
\hline
\end{tabular}

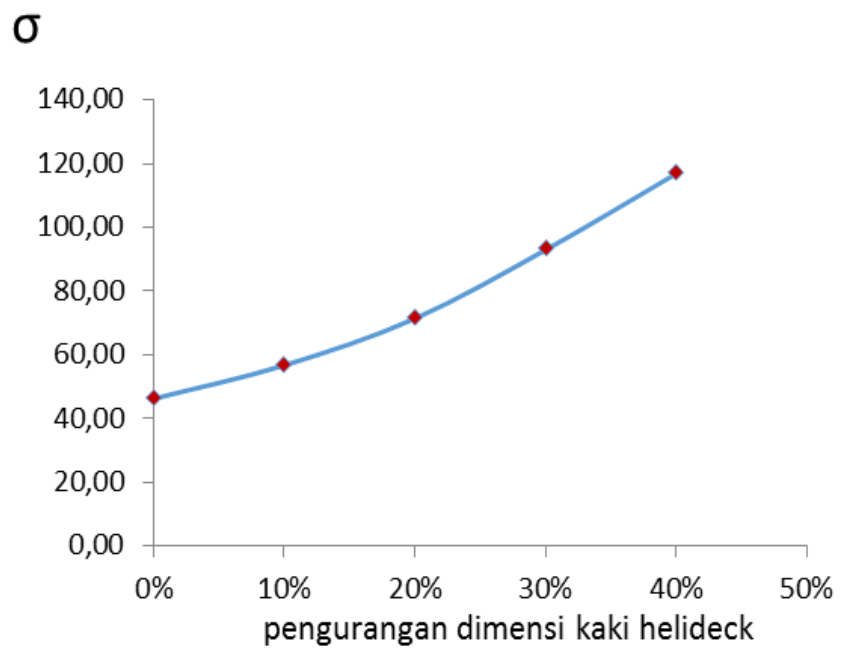

Gambar 7. Tegangan terhadap pengurangan dimensi

- Model brace Y

Dari hasil running analisis pada model brace Y maka diperoleh tegangan maksimum yang bekerja dan nilai $I R$ seperti pada Tabel 5 .

Tabel 5. Tegangan dan IR model brace $\mathrm{Y}$

\begin{tabular}{ccc}
\hline $\begin{array}{c}\text { Pengurangan } \\
\text { dimensi }\end{array}$ & $\begin{array}{c}\boldsymbol{\sigma} \\
\left(\mathbf{N} / \mathbf{m m}^{2}\right)\end{array}$ & $\boldsymbol{I R}$ \\
\hline $0 \%$ & 46,60 & 0,40 \\
$10 \%$ & 56,66 & 0,48 \\
$20 \%$ & 72,31 & 0,62 \\
$30 \%$ & 93,69 & 0,80 \\
$40 \%$ & 116,50 & 1,03 \\
\hline
\end{tabular}

Hasil running analisis model brace $\mathrm{Y}$ menunjukkan tegangan kerja pada pengurangan dimensi $0 \%$ sebesar $46,60 \mathrm{~N} / \mathrm{mm}^{2}$ sedangkan tegangan kerja maksimum pada pengurangan dimensi $40 \%$ sebesar $116,50 \mathrm{~N} / \mathrm{mm}^{2}$. Adapun nilai tegangan terhadap pengurangan kaki struktur seperti pada Gambar 8.

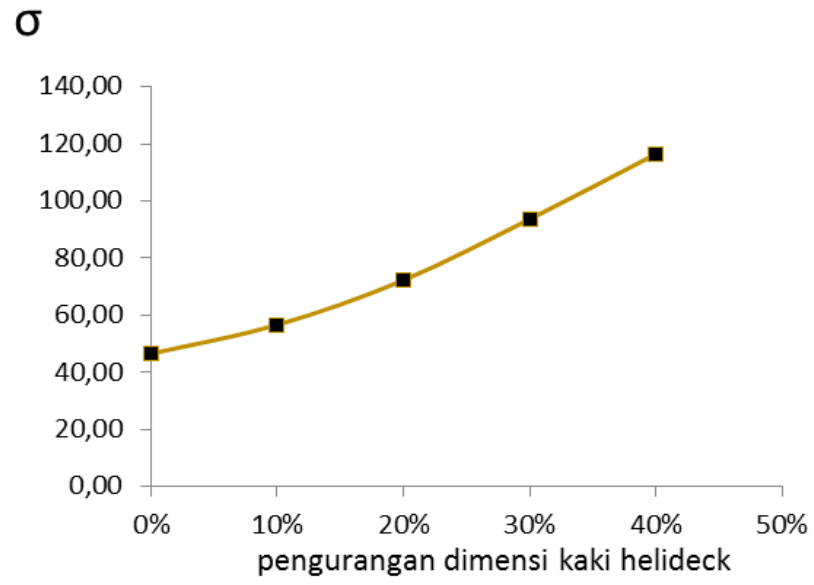

Gambar 8. Tegangan terhadap pengurangan dimensi

- Model brace $\mathrm{K}$

Hasil analisis antara tengan kerja maksimum dan nilai $I R$ untuk model brace $\mathrm{K}$ dapat dilihat pada Tabel 6.

Tabel 6. Tegangan dan IR model brace $\mathrm{K}$

\begin{tabular}{ccc}
\hline $\begin{array}{c}\text { Pengurangan } \\
\text { dimensi }\end{array}$ & $\begin{array}{c}\boldsymbol{\sigma} \\
\left(\mathbf{N} / \mathbf{m m}^{\mathbf{2}}\right)\end{array}$ & $\boldsymbol{I R}$ \\
\hline $0 \%$ & 48,39 & 0,45 \\
$10 \%$ & 59,36 & 0,54 \\
$20 \%$ & 74,65 & 0,67 \\
$30 \%$ & 96,99 & 0,87 \\
$40 \%$ & 131,62 & 1,19 \\
\hline
\end{tabular}

Hasil running model brace $\mathrm{K}$ menunjukkan nilai tegangan kerja pada pengurangan dimensi $0 \%$ sebasar $48,39 \mathrm{~N} / \mathrm{mm}^{2}$ sedangkan tegangan kerja untuk pengurangan dimensi kaki struktur $40 \%$ sebesar 131,62 $\mathrm{N} / \mathrm{mm}^{2}$.Adapun grafik tegangan kerja terhadap pengurangan dimensi dapat dilihat pada Gambar 9.

Hasil analisis pengurangan dimensi kaki struktur helideck untuk semua model brace dapat dilihat tegangan kerja terbesar untuk pengurangan dimensi kaki $40 \%$ terjadi pada model brace $\mathrm{K}$ dengan tegangan kerja maksimum sebesar 131,62 $\mathrm{N} / \mathrm{mm}^{2}$ sedangkan untuk tegangan kerja terkecil pada model brace X sebesar $114,12 \mathrm{~N} / \mathrm{mm}^{2}$. Adapun nilai $I R$ untuk masing-masing model brace dapat dilihat pada Tabel 7 . 


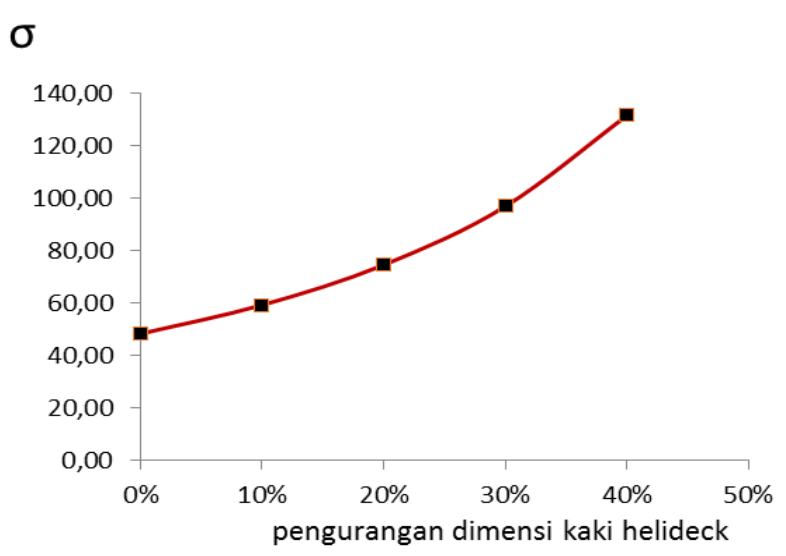

Gambar 9. Tegangan terhadap pengurangan dimensi

Tabel 7. IR Pengurangan dimensi kaki helideck

\begin{tabular}{cccccc}
\hline \multirow{2}{*}{ BRACE } & \multicolumn{5}{c}{$\boldsymbol{I R}$} \\
& $\mathbf{0 \%}$ & $\mathbf{1 0 \%}$ & $\mathbf{2 0 \%}$ & $\mathbf{3 0 \%}$ & $\mathbf{4 0 \%}$ \\
\hline $\mathrm{Y}$ & 0,4 & 0,48 & 0,62 & 0,8 & 1,03 \\
$\mathrm{X}$ & 0,4 & 0,48 & 0,6 & 0,78 & 0,99 \\
$\mathrm{~K}$ & 0,45 & 0,54 & 0,67 & 0,87 & 1,19 \\
$\mathrm{~N}$ & 0,42 & 0,5 & 0,62 & 0,81 & 1,04 \\
\hline
\end{tabular}

Dari Tabel dapat dilihat nilai $I R$ terbesar untuk pengurangan dimensi kaki $40 \%$ terjadi pada model brace $\mathrm{K}$ dengan nilai $I R=1,19$ sedangkan untuk nilai $I R$ terkecil terjadi pada model brace $\mathrm{X}$ dengan nilai $I R=0,99$, untuk model Y $I R=1,03$ dan model $\mathrm{N} I R=1,04$. Untuk melihat perbandingan nilai $I R$ terhadap pengurangan dimensi kaki struktur untuk masing-masing model dapat dilihat pada Gambar 10.

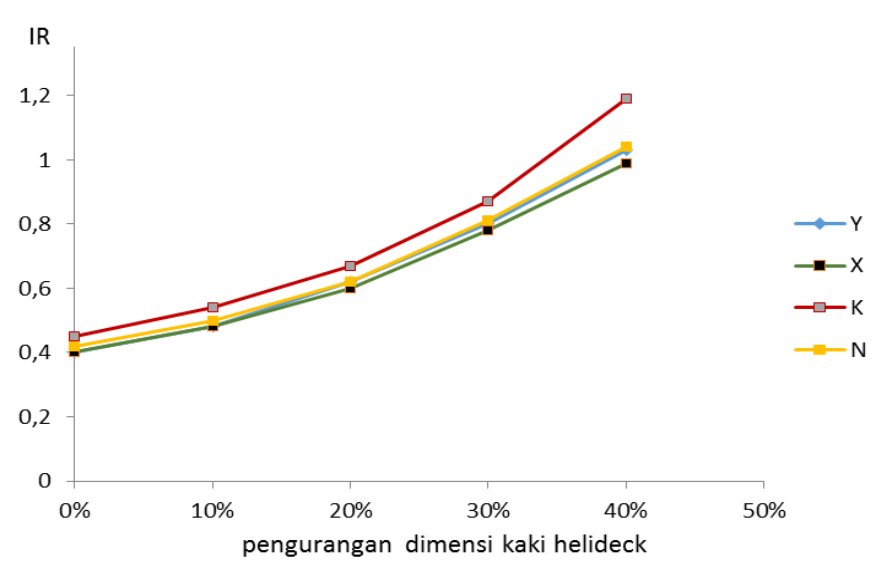

Gambar 10. IR terhadap pengurangan dimensi kaki
struktur helideck

Hasil perhitungan menunjukkan model variasi brace terhadap pengurangan dimensi kaki struktur mengalami peningkatan tegangan dan interaksi rasio secara linear untuk masing-masing model brace struktur. Semakin kecil penampang kaki struktur helideck maka semakin besar pula tegangan kerja yang terjadi sehingga nilai $I R$ dari masing-masing model brace kaki struktur helideck menjadi lebih besar. Perbedaan kekuatan antar model brace pada struktur cenderung lebih besar pada saat pengurangan dimensi struktur yang lebih besar sehingga dapat disimpulkan semakin kecil kaki struktur helideck maka semakin besar pengaruh model brace terhadap kekuatan kaki struktur helideck dalam menahan beban pendaratan darurat helikopter.

\section{Kesimpulan}

- Tegangan kerja maksimum terjadi pada pendaratan darurat arah diagonal menyimpang 4 meter dari lingkarang pendaratan normal dengan tegangan kerja sebesar 49,86 N/mm² dan nilai $I R 0,45$.

- Model brace yang paling kuat dalam menahan beban pendaratan darurat helikopter adalah model brace $\mathrm{X}$ dan yang paling lemah adalah model brace $\mathrm{K}$.

- Dimensi kaki struktur helideck masih dapat direduksi sebesar $40 \%$ dengan menggunakan model brace X dengan nilai IR 0,99.

\section{Referensi}

[1] Vaghefi M, Hassan Bagheri and Mohebpou S.R, 2013. Nonlinear Analysis of Offshore Helidecks Due to the Helicopter Emergency Landing Loads, Department of Civil Engineering, Persian Gulf University, Boushehr, Iran. Middle-East Journal of Scientific Research 13 (10): 1351-1358.

[2] Muis Alie, M.Z., 2016. The Effect of Symmetrical and Asymmetrical Configuration Shapes on Bukling and Fatique Stength Analysis of Fixed Offshore Platform. International Journal of Technology (IJTech), Indonesia.

[3] M. Zain Fajar Ramadhani dan I Ketut Aria Pria Utama, 2018. Analisis Aliran Fluida Udara akibat Pendaratan Helikopter terhadap Permukaan Helideck pada Kapal. Jurnal teknik ITS Vol. 7, no. 1, 2337-3520, Indonesia

[5] Park JS and Seo JK, 2017. Deformation-Based Design Method of Aluminium Helideck for Eurocode 9. Journal of Applied Mechanical Engineering, DOI: 10.4172/2168-9873.1000258, Korea.

[6] Api Recomended Practice 2a-Wsd (API RP 2A-WSD), 2002, "Recomended Practice for Planning Designing 
and Construction Fixed Offshore Platform-Working Stress Design" American Petrolium Institute, Amerika Serikat.

[7] Erlina k, Ari, M dan dhika A.P, 2016. Analisis Kekuatan Terhadap Rencana Struktur Penyangga Helideck Pada Bangunan Lepas Pantai. Proceedings Confrence on Design Manufacture Engineering and Its Aplication. Indonesia.

[8] I-Wen Chen, Bao-Leng Wong, Yu-Hung Lin, Shiu-Wu Chau and Hsin-Haou Huang, 2016. Design and
Analysis of Jacket Substructures for Offshore Wind Turbines Department of Engineering Science and Ocean Engineering, National Taiwan University, Taipei 106, Taiwan. Mdpi Journal Energies.

[9] Direktur Jenderal Perhubungan Udara KP 40, 2015. Standar Teknis Dan Operasi Peraturan Keselamatan Penerbangan Sipil Bagian 139 Volume II Tempat Pendaratan Dan Lepas Landas Helikopter, Indonesia.

[10] Burt, Bomel Jhon, 2002. Offshore Helideck Design Guidelines for the Health and Safety Executive, Inggris. 